\title{
THE PHENOMENON OF THE SAINT PETERSBURG VARIANT OF THE REGULAR CITY
}

\author{
Leonid Lavrov¹, Feodor Perov ${ }^{2}$ \\ ${ }_{1,2}$ Saint Petersburg State University of Architecture and Civil Engineering, \\ Vtoraja Krasnoarmejskaja ul. 4, St. Petersburg, 190005, Russia. \\ 1 leonid.lavrov@gmail.com,. f.perov@gmail.com
}

\begin{abstract}
Saint Petersburg building development formed by the first third of the 19th century is under review. At that time the idea of regular city design was put into effect to the fullest extent. The most significant and specific quantitative data are given based on literature references and drawings. It is shown that besides strict administration over design and construction activities, the following basic conditions influenced on achievement of such result: parceling at the initial stage of the city organization, metropolitan ambitions supported by appropriate financing, considerable volumes of state orders, completion of main building development within a short period of time, involvement of skilled professionals.

Fundamental distinctive features are found out between regular design of Saint Petersburg's urban development and traditional European city as well as an "ideal city".
\end{abstract}

\section{Keywords}

Saint Petersburg architecture, classicism, development control, parceling, order placement

\section{Introduction}

The paper purpose is defined by the following statement of city planning theoretician V. Ostrovskiy: "In fact, it was not architects who constructed big modern cities, it was legislators who created a structure to be implemented by interested parties. Architects were only allowed to apply external embellishment to unchangeable structure determined by prevailing conditions." (Ostrovsky, 1979) The paper determines influence of particular conditions on organization of Saint Petersburg regular building development. Traditionally, history of architecture focuses on unique facilities such as sanctuaries, palaces, and castles. The main peculiarity of the historic downtown of Saint Petersburg is its architectural complex, where a residential building, as an object of mass building development, is a meaningful element of urban complex. Analysis of residential building development of the city allows to cover the most significant aspects.

\section{Materials and Methods}

Data of literature, drawings, maps and schemes are used; Vista of Nevsky Prospect in 1830-ies is under thorough analysis (Kotelnikova, 1974; Margolis, Sementsov, 2004). The theory and subjective assessments related to architectural features of Saint Petersburg are compared with documentary evidences given, in particular, in works by S.V. Sementsov $(2006(1,2))$. The most significant factors of regular city building development organization are found out. Comparison of architectural and urban planning features of Saint Petersburg with a traditional European city as well as with an "ideal" fortress city clearly demonstrates peculiarity of architectural look of Saint Petersburg.

\subsection{0ies - peak of "regular city design" implementation in Saint Petersburg}

In 1833 , population of the city equaled 440,000 people. It was one of the largest European metropolises. The number of buildings equaled 7,976 , including 5,246 of wooden buildings. Small wooden constructions composed the building development at the northern bank of the Neva river (at the Petrograd Side), at the western part of Vasilyevsky Island and to the south of the Fontanka River. The most of stone buildings (total of 2,730) were located in the center of the city between the Neva and Fontanka rivers. This particular part of the city represented the appearance of the Russian Empire capital city. Its urban planning features complied with the standards of an "ideal city": clearly delineated regular urban planning was applied onto 
completely flat surfaces of the Neva Delta isles. Intersection of straight streets and loose river bends created exceptional view of this area. By that time all streaming waters within the city center were embanked with granite and cast-iron enclosures, trees were planted at the banks. These made the local landscape charming.

Organization of urban building development complex in the city center was completed. Saint Isaac's Cathedral was still surrounded by construction trestle, but all architecturally iconic buildings were already on their places, i.e. complex of the Spit of Vasilyevsky Island, the Admiralty building, Architect Rossi street, architectural complexes of Nevsky Prospect area and near Palace Square. These dominant structures perfectly harmonized with high-quality background building development, thus ensuring integrity of Saint Petersburg urban environment. A.N. Benois highly appraised the city center landscapes: "Its beauty is in its entirety or, more correctly, solid lumps, large ensembles, wide panoramic views." (Benois, 1902).

Figure 1 shows important compositional function of Nevsky Prospect. To the north its axis looks out onto the group of squares surrounding the Admiralty building and linked with the Neva water area. This place commands a good view on the Spit and the Peter and Paul Fortress. The area of Nevsky Prospect between the Fontanka river and the Catherine Canal opens to Mikhailovskaya Square and Ostrovsky Square along with Teatralnaya Street (Architect Rossi street).

Principle of architectural complexes strongly affected organization of urban buildings image. Image of a building was determined not by its functional purpose, but by its place in general view of urban landscape. There were just a few accenting elements and all other buildings were secondary objects of the composition. Residential and commercial buildings, barracks integrated into single area represented a kind of "fabric" and dominant structures stood out of this background.

Organization of Mikhailovskaya Square complex is typical to this approach. According to the plan of K.I. Rossi, the palace of Grand Duke Mikhail Pavlovich of Russia should be the dominant of the complex: a presentable building was located in the center of the composition at the end of Mikhailovskaya Street with a view to Nevsky Prospect. In parallel with design of the Palace, K.I. Rossi drew developed views along the building lines of the Square and Mikhailovskaya Street and drafted frontispieces of all buildings. Using these sketches, all other architects were involved into development of design and planning of each particular building. Residential buildings, theater and the Gentry assembly did not distinguish from each other.

Architect Rossi street is considered to be a significant architectural complex - the propylaea opening towards the Alexandrinsky Theater. The

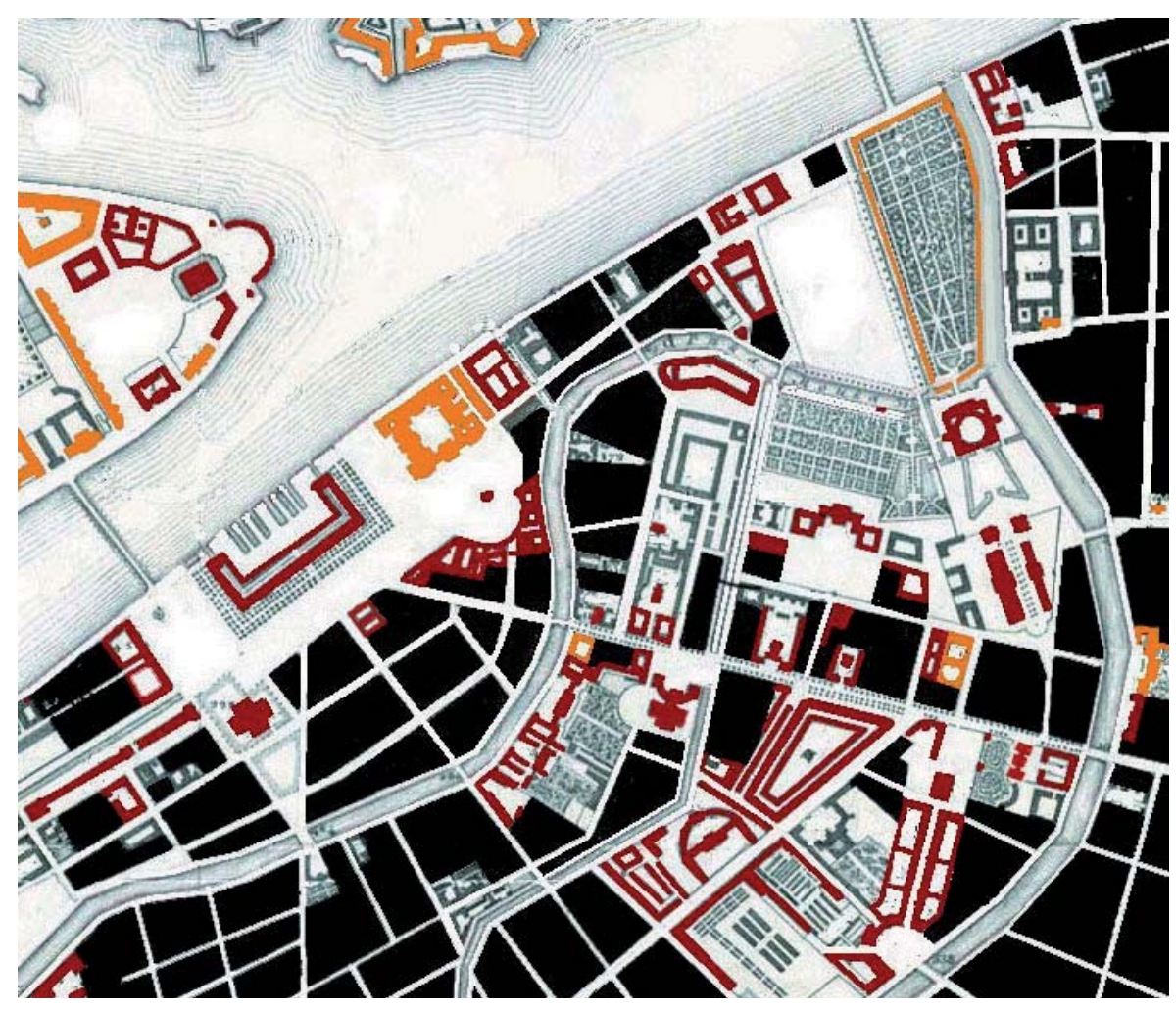

Fig.1. Scheme of the Saint Petersburg central area, 1821. The following colors denote civil buildings: yellow - Baroque, red - Classicism 
street is 220 meters long and is formed with two totally symmetrical buildings located opposite to each other. Building \# 1/3 was constructed as a place of military educational establishments, but the Ministry of National Education and Ministry of Internal Affairs were finally located there. Building \# 2 was constructed as a commercial apartment building and at the beginning its ground level consisted of small shops; while apartments and a hotel were located on the upper levels. But soon the building was assigned to the Directorate of the Emperor's Theaters. There

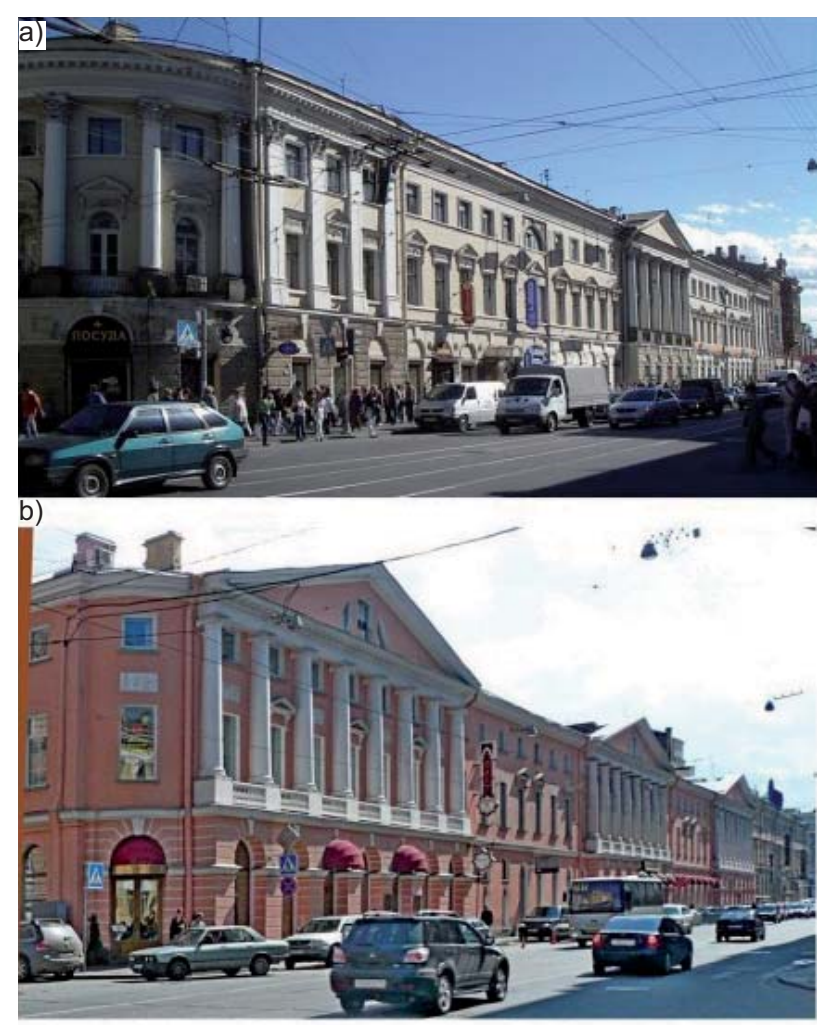

c)

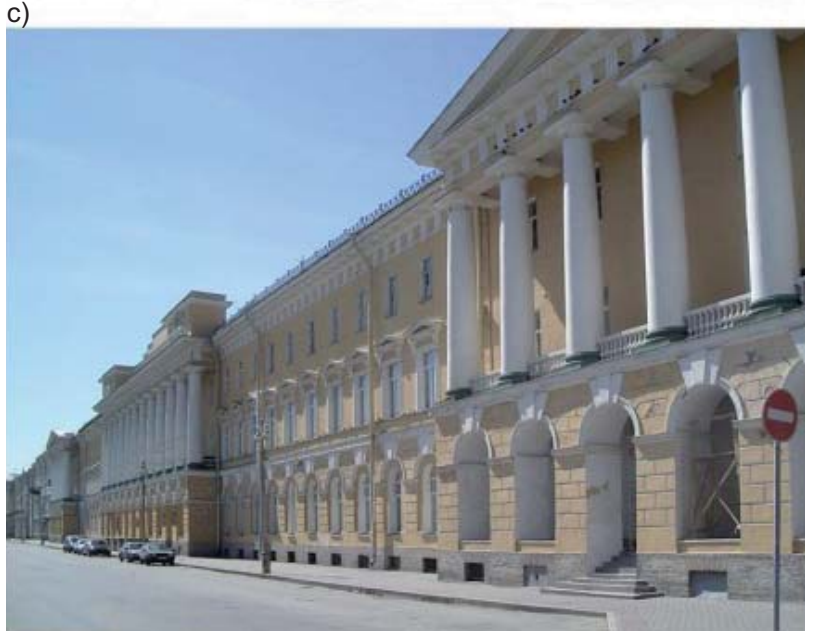

Fig. 2. Appearance of buildings with various types of functionality (contemporary photographs):

a - residential house of Yakovlev, Sadovaya street; $b-$

administrative building of the National Revenue Distribution Center, Sadovaya street; c - barracks of Pavlovsk regiment at the Field of Mars are no differences between appearances of these buildings, their frontispieces are totally identical.

Presentability of buildings was of importance in the capital. Residences of the Emperor's family members, palaces of the court notables, administrative buildings, objects of the Military Department constructed in the city center set the style. Their solemn but austere and official appearance served as an example for residential building development. If in a "European city" a town hall often looked like a house of a well-to-do man, then in Saint Petersburg a commercial apartment building was constructed to be similar to palace. Fig. 2 shows similar appearances of a residential house, administrative building and barrack in the center of Saint Petersburg.

The main street view of that time is documented in Vista of Nevsky Prospect by V.S. Sadovnikov (Kotelnikova, 1974). It depicts 108 buildings, including 98 residential buildings. Uniformity of the picture is surprising: all structures consist of 3-4 storeys and have long frontispieces. Buildings stretching along 9-13 axes are prevailing, but longer buildings are not rare objects: building \# 30 consists of 19 axes, building \# 18 consists of 31 axes, building \# 20 consist of 37 axes (building \# 29 is an exception as its frontispiece opens to Nevsky Prospect and it is 4 windows long). The style is also common: 107 building out of 108 are the examples of classicism (except for Beloselsky Belozersky Palace that is of baroque style). The Vista shows a unique situation as Nevsky Prospect of 1830 -ies with its even (in all aspects) building development could be considered as an illustration of utopian "ideal city".

Classical building development prevailed and determined the views of urban landscapes. The squares had clear geometry outlines. The face of building block development stretched along the straight line. Buildings located along the streets had no gaps between, they were adjacent to each other and had the same height. Thus, a wall was created which stretched from one crossroad to another. Its length could equal to $447.3 \mathrm{~m}$ on Vasilyevsky Island, to $426-553.8 \mathrm{~m}$ at the Liteyny area where building blocks were of significant size.

3.2. 1703-1717 - Saint Petersburg is a "window on Europe", a new city with dispersive urban planning

A.N. Benois wrote: "Rush towards the West has existed from the very origin of Saint Petersburg. Even its foundation was a result of this rush." (Benois, 1902).

Peter the Great considered foundation of Saint Petersburg a determinative step towards implementation of a strategic plan for strengthening relations with Europe and was ready to face all the difficulties in pursuing this goal. And there were a number of difficulties. Saint Petersburg was 
founded on a sparsely populated territory without any considerable settlements. The nearest Russian city was Novgorod which was located almost 200 $\mathrm{km}$ apart. But there were no suitable roadways to travel. Waterway was the only possible method of communication with central Russia. Under these conditions a fortress was erected on a small island in the Neva Delta. On the inland, to the north of this fortress, a temporary settlement was arranged in a random way. At the same time, on the southern bank of the Neva a shipbuilding yard was founded; and buildings of palace type along with the Summer Garden were constructed nearby. The Governor Palace, a building for museum and scientific establishments were founded on Vasilyevsky Island. In 1712, government authorities were re-located to Saint Petersburg. Residential settlements along the rivers expanded. On the bank of the Gulf of Finland in Peterhof, the Palace of Emperor was found. A possibility of main building development on the Kotlin Island was considered. The first decade of Saint Petersburg existence impresses with variety and spread of sites developed. New buildings were constructed in scattered way: there was no documentation to regulate these activities. There was no single general city planning scheme. Peter the Great was to decide on appearance of the Empire's capital.

He found prototypes for a new city when traveled throughout Europe. We cannot determine the particular details of diversity which impressed him the most. A.N. Benois used a general term of a "European city" (Benois, 1902). This form allows to discuss views of multiple populated localities, first of all those of randomly developed historical settlements.

By that time history of the most "European" cities accounted for many centuries. A successful city had a right to its own market, possibility of self-administration based on its own laws, had its own court and clear borders (frequently such borders were represented with fortified walls). A medieval city (in particular, a city with a status granted on the basis of Magdeburg rights) attracted people from non-urban areas with a possibility to get some of the privileges ("atmosphere of a city makes people free"). So, as a rule, such city was densely populated and developed. The community attempted to ensure each citizen with the same rights standard conditions for house construction within the city area; it controlled land-use conditions and established the land size. The idea of such city could not be implemented by Peter the Great: firstly, the rules of Russian absolute monarchy had no allowance for self-administration of cities; secondly, due to desolation of the near-Neva area no one could reckon upon accidental drift of the population within this period of time.
When arranging a European-type city, Peter the Great deemed it necessary to employ the services of foreign specialists. They considered the conditions of Saint Petersburg non-conventional and comparable with overseas foundation of fortified tactical localities by Europeans. When designing the capital of Russia, it was decided to base on experience of "regular city" design in Europe that gained widespread in the form of a residence city or fortress city. Anyway, the developments provided in 1715-1717 by JeanBaptiste Le Blond and Domenico Trezzini were based on an "ideal city" and were considered as a starting point of Saint Petersburg arrangement on the basis of a planning scheme.

\subsection{7-1737 - a new city with a center on Vasilyevsky Island}

Le Blond and Trezzini's projects took into account the ambitions of the huge Empire capital city. So these projects differed from European concepts of an "ideal city" by giant size of the territory covered and colossal sizes of urban elements (the main square proposed by Le Blond had overall dimensions of 446.2 x $446.2 \mathrm{~m}$ (Sementsov, 2006(2)). Le Blond and Trezzini's concepts did not match by many aspects, but both of them agreed that Vasilyevsky Island should be the city center and the location for the bulk of the population. Peter the Great also supported this idea. In a short time, on the eastern point of the Island, the base of the important functional center of the future capital city was founded. Colossal structures that were novel to this area were erected on the swamp meadow: administrative complex of Twelve Colleges was 400 meters long; and perimeter of Gostiny Dvor building equaled 740 meters. These buildings outlined the area of the future large presentable square compatible in its size to those of some medieval European cities.

Upon development of the other parts of the Island, the concept of large scale was implemented as well. Rectangular street breakdown was determined by base dimensions of a residential block, namely $447.3 \times 140.6 \mathrm{~m}$. The main traffic road of the Island was determined by the distance between the lines of building frontispieces equaling 85 meters and the width of cross streets was determined at about $30 \mathrm{~m}$. These overall dimensions were determined based on designing location of channels along the axes of these streets. No commercial cost was determined for the land in the new city, thus large areas could be allocated for the purpose of building development. They had the depth of about 30-40 m. Based on the length of frontispiece line, they were divided into small (one module, $21.60 \mathrm{~m}$ in length), average (one and a half module, i.e. $32.40 \mathrm{~m}$ ) and large (two modules, $43.20 \mathrm{~m}$ in total length) ones (Sementsov, $2006(1,2))$.

Two main types of building development were worked out. Within the areas where ambitions of a capital city were of critical importance (the Neva 
embankments), structural volumes consisted of 2-2.5 storeys, were adjacent to each other with their end walls and formed a continuous face frontispiece of the block. They reminded Peter the Great the landscapes of Dutch cities he loved so much. However, the most common were town mansions designed for living of a single family and capable of cattle handling, as well as garden laying-out. Such houses retained traditional views of Russian cities.

Modest buildings prevailed consisting of one or one and a half storey. It was explained by financial reasoning of building owners and lack of desire to invest in construction activities, rather than technical capabilities. Accommodation of the new capital was a difficult process as the city did not attract people. There was no motivation for construction activities with the purpose of profit generation. So, as a rule, each housing building had one household. If the land was allocated to craftsmen transmigrated to Saint Petersburg, then their houses in some cases were built at the government expense. Individuals were forced to invest into building development. In 1713, the following ordinance was issued: all individuals considered as noblemen and nobility having minimum of 30 peasants were to reside in the capital on continuous basis and have their own houses in Saint Petersburg (this method was approved in France by Louis XIV: only noblemen could get a promotion; if an individual left for another location, he lost his privileges).

Some of the structures were located along the building line. But they were small and occupied only a part of the area; fire breaks were retained between such buildings. Wooden and mud-walled semipermanent houses prevailed. To make these houses look more presentable, they were painted as red brick walls. Only high-rank officials had ambitious two-storey palaces. House of Menshikov, the General Governor, stood out of the other buildings. It was a three-storey building with a basement.

Only a portion of intentions of Peter the Great was implemented. He died suddenly in 1725. At that time there were 109 stone building in the city; the population reached 40,000 people.

The following conditions determined the city appearance and the ways of its organization at the beginning:

- the city was founded at the location without any infrastructure

and material-supply base;

- the state had the title to land;

- the city accommodation and building development were forced ("administrative resource");

- open market rules did not work;

- the state was the main investor;

- the system of administrative control over building development started up;
- skilled professionals, mainly the foreign ones, were involved into design and construction activities;

- one of the main objectives was creation of presentable architectural appearance of the new capital.

After the founder's death, Saint Petersburg faced a sequence of difficulties:

- for the period of 1728-1730. the Imperial Court and governmental establishments were moved to Moscow. The city lost its functions of a capital. Life in Saint Petersburg faded. Many of its citizens who were forced to move to the northern capital left Saint Petersburg.

- in 1736 and 1737 two terrific fires destroyed the city. Only one third of the buildings survived in the central Admiralty area of the city (Lisovsky, 2004). In principle, the concept of the city development had to be renewed after those fires.

3.4. 1737-1837 - a city of baroque and classicism with the center at the Admiralty Side

When the Emperor's family returned to Saint Petersburg, the city center was renewed at the Admiralty Side. Main government establishments were located here, new Winter Palace was constructed in a short period of time. Construction activities revived. In 1737, immediately after the wild fires, a planning scheme was developed under the direction of P.M. Yeropkin. This scheme determined layout of three main traffic roads of the city that began from the spire of the Admiralty building, and outlined planning solution for other areas, including those located to the south of the Fontanka river. This plan can be considered as an important document. It determined the second stage of Saint Petersburg regular development.

At this stage some of the conditions determining the building development changed:

- forced city accommodation and private construction used at the time of Peter the Great were cancelled;

- the city became attractive and the amount of private investments equaled to the state financial support;

- the state remained the largest investor financing construction of administrative buildings, Ministry of Defense objects, hospitals and educational institutions;

- the required infrastructure was created (main traffic roads and channels); quays in the city center were reinforced and bridges were constructed;

- tough administrative control over the building development was finalized and effectively implemented;

- design and construction activities were carried out by skilled professionals (numerous outstanding architects and engineers worked in Saint Petersburg); 
- importance of the capital architectural appearance presentability was highly emphasized;

- stone buildings comprised the smallest part of the city buildings;

- brick structures with plastered frontispieces prevailed in the city center.

By the end of the 18th century, living conditions of Saint Petersburg had changed. Voluntary accommodation of the capital led to the need in new residential buildings. Motivation for civil engineering development appeared. The building development became denser. Extra storeys were added to residential buildings. One- and two-storey mansions were upgraded into multi-storey buildings suitable for several families' living.

In 1765, building regulations were put into effect, aiming at improvement of royalty appearance of the capital city:

- it was decided to arrange buildings in a single frontispiece so that they were adjacent to each other. Breaks within the building row were filled with the structures and the length of each frontispiece was equal to the length of the land along the building line. As a result, building block development became to appear as a single wall from one cross road to another;

- a rule of "single cornice" construction was put into effect. In remote areas one- and two-storey buildings existed within one building block. But in the city center increase in the building height complied with architects' concepts. In 1765, the Building Committee asked Catherine II to set the height of embankment building at the level of 10 sagenes in order "the structures along the Neva river complied with stone embankment under construction". By 1830, three- and four-storey buildings prevailed at Nevsky Prospect and at some other areas of importance.

However, when five-storey buildings were constructed, the authorities decided to constrain ambitions of individual building owners. According to the ordinance executed by Nicholas I, height of private buildings could not be above the cornice of the Emperor's residence, i.e. Winter Palace (23.47 $\mathrm{m})$. This action was taken with consideration of European experience where constrains were applied to building height due to fear of building collapse and for the purpose of fire safety as well as with regard to prestige.

Since mid-18th century, trend of areas consolidation and buildings integration can be observed in the city center. Some particular examples: in 1757-1758, two areas on the Neva embankment were joint together and standard residential buildings constructed here under the project of S.I. Chevakinsky were rearranged into a single building (currently building \# 11, Lieutenant Schmidt embankment). In 1791-1793, L. Ruska erected a two-storey building with the length of 27 axes on two consolidated areas of the 1st line on Vasilyevsky Island.

Administrative control related to design and construction activities with regard to style became extremely tough at this period of time. For example, the Committee headed by A. Betancourt targeted at the "correctness, beauty and propriety of each building as applied to the entire city" (Sementsov, 2006(1)). Thus, uniform style of building development in the center of Saint Petersburg was achieved by natural focus of architects on the use of the leading architectural concept of that time as well as by direct measures of control over design and construction activities. A phenomenon of Saint Petersburg comes out in integrity of its appearance as a result of cooperation between a number of outstanding craftsmen of the "age of classicism the golden age of the capital city art of building" (Benois, 1902).

In the process of restoration, the buildings got their new appearance meeting fashion trends and administrative requirements. The possibility of frontispiece renewal in Saint Petersburg was facilitated with the use of plaster intended for creation of face cover. So, at relatively low costs it was possible to change the style characteristics. The process was widely implemented in the beginning of the 19th century when classical frontispieces were applied to baroque buildings. A quarter of the buildings depicted on the Vista of Nevsky Prospect subjected to this change. Concepts of urban development dated back to the 18th century were retained, but Peter's Petersburg was buried under the number of added extra storeys and covered with decorative plaster.

\subsection{0-1917 - post-classicism in Saint Petersburg}

The period of the city rapid growth: in 1850 the population of the city was 487,000 people; in 1891 it equaled to $1,033,000$; in 1900 it equaled to $1,416,000$; in 1917 it equaled to $2,300,000$.

The stage of classicism is over. The concept of regular building development is criticized more often. At that, traditional and randomly developed settlements are claimed to be the positive options for "ideal cities" of Europe. According to an emotional saying of N.V. Gogol, "new cities have no appearance: they are too correct, too smooth... An old-style German town with its narrow streets, colorful houses and high bell towers looks more vivid" (Gogol,1950). This saying amazingly complies with the assessment of "ideal" city fortress arrangement from Laugier, a French theoretician (1713-1769): “... tasteless straightness prevails there along with cold uniformity; it makes us regret for our old disordered cities..." (Savarenskaya, et al., 1989).

In early 1840-ies the authorities decided it reasonable to refuse from "uniformity in urban 
development". Decisions on formation were taken by Emperor's orders of 1843-1844 which dictated to use frontispieces of "non-uniform appearance". By administrative orders it was authorized to "paint residential houses with different colors from the outside" (Sementsov, 2006(1)).

Conditions of building development were changed:

- development and upgrade of the required infrastructure were carried out;

- non-state investments were made in the main construction volume;

- aggregation of capital at individual house owners increased; loan scheme for building owners improved;

- building development control was relaxed; but the rule of constrained building height was still applicable;

- no more attention was paid to presentability of the city architectural appearance;

- design and construction activities were carried out under direction of qualified professionals;

- construction technologies, structures and materials were developed.

Rapid growth of the population, increased demand in residential buildings inspired construction fever. Improved financial abilities of building owners led to increase in building dimensions: "a building owner bought several neighboring areas and created a single large block by means of old structures' rebuilding and overbuilding" (Punin, 1981). Relaxed building regulations were put into effect. Five- and sixstorey buildings were allowed in the historical center. Appearance of Petrograd and Vyborg Sides, areas behind the Fontanka river and near Smolny were transformed. In 1887 there were 96.5 residents at the average in a single residential building in Petersburg; 48.5 residents in Moscow; 32.6 residents in Paris; 59.4 residents in Berlin ("barrack of Europe") and 7.8 residents in London (Kirichenko, 1963).

Constraints on buildings height were still in effect in Saint Petersburg, but the city started to lose its individuality. As in any other European metropolises, the rule of building development in a single frontispiece was not effective anymore. Huge residential building blocks were constructed with courts of honour and internal yards systems. The streets were filled with structures having various decorations of their frontispieces. Egyptian and Moorish styles were used as well as neo-gothic, neo-renaissance, neo-baroque ones.

Restoration of number of houses in the city center damaged the landscapes of classical complexes. Frequently, only building frontispieces were renovated in a stylish way. Advertising panels worsened the appearance of streets. Design uniformity of Nevsky Prospect depicted in Sadovnikov's Vista was violated and within further "150 years the prospect turned into a sampler of styles used in Petersburg architecture - from baroque to modern and neoclassicism" (Kirikov et al., 2004).

\subsection{7-late 1950-ies}

The following data on change in the population are evidencing the hard time of the city: 1917 2,300,000 people; $1920-740,000$ people; 1939 3,190,000 people; 1945 - 947,000 people; 1959 $3,320,000$ people.

Conditions of building development arrangement:

- breaks in construction activities during the Civil war and the Great Patriotic war;

- the city lost its function of the capital city and, therefore

- its financial possibilities were decreased;

- the state became the main investor again;

- all the city land got the status of state property;

- implementation of tough control over design and construction activities directly applied to architectural style.

At this time rather small amount of construction work was carried out. But it became the history of domestic architecture due to residential areas (rus. zhilmassiv), community houses and the houses for skilled professionals of constructivism time. The time of Stalinist Empire style is of interest due to renewal of "single cornice" concept, application of transformed compositional methods and the Russian classicism stylistics. During the post-war period, historical appearance of a number of buildings in the city center was restored.

\subsection{0-1990-ies}

Large-scale housing construction programs were approved; new large "bedroom towns" appeared at the city outskirts, that were designed and implemented as residential communities, so they can be classified as "generated settlements".

\section{Results of investigation}

Regular building development of Saint Petersburg which had taken shape by 1830 was implemented on the basis of projects developed by skilled professionals and under the conditions of tough administrative control and monitoring (as well as over style of the buildings). However, it was not a one-step action and was implemented in series of steps:

1717 - generation of a concept of a regular city design, its implementation through a number of urban planning and architectural aspects; implementation of parceling idea and allocation of large areas for building development.

1737 - creation of the long-term development plan based on the regular city concept, determination of the city center, setting up of parceling idea and allocation of large areas for building development.

1765 - switching to urban development system with "house-to-house frontispiece" and "single 
cornice"; increase in private investments in building development.

1830-ies - peak of regular building, uniformity of the city center style.

1840-ies - statutory refusal from tough regulation over architectural style; height constraints retained.

1900-2000-ies - height constraints retained in the city center; generation of the protection system for historical sites.

Table 1 lists the conditions which determined the regular design of building development and style uniformity in the Saint Petersburg center:
- the city was founded in a new place, the state had the title to all lands, and that facilitated freedom of urban planning and allowed to allocate large areas for building development;

- status of the capital city determined state intensive investments (folk words of wisdom: "Moscow was constructed through the centuries, Petersburg - through millions!") and ambitious attitude to the city architectural appearance;

- availability of tough building regulation system covered the aspects of architectural style as well;

- limited period of time for main building development allowed to arrange its architectural properties within prevailing style, i.e. classicism;

Table 1

Comparison of factors determined building development character of Saint Petersburg and of European cities

\begin{tabular}{|c|c|c|c|c|}
\hline \multirow[b]{2}{*}{ No. } & \multirow[b]{2}{*}{ Feature } & \multicolumn{3}{|c|}{ Cities } \\
\hline & & $\begin{array}{l}\text { Saint Petersburg } \\
\text { 18th-early 19th } \\
\text { centuries }\end{array}$ & $\begin{array}{c}\text { Traditional } \\
\text { "European" city }\end{array}$ & $\begin{array}{l}\text { "Ideal" city } \\
\text { fortress }\end{array}$ \\
\hline \multirow{12}{*}{$\begin{array}{l}\text { Organizational } \\
\text { and urban } \\
\text { planning aspects }\end{array}$} & Status & $\begin{array}{l}\text { capital city of the large } \\
\text { state }\end{array}$ & $\begin{array}{l}\text { city-state, country } \\
\text { town }\end{array}$ & fortified locality \\
\hline & Population & $\begin{array}{l}\text { several hundred } \\
\text { thousand of people }\end{array}$ & $\begin{array}{l}10000 \text { people } \\
\text { maximum }\end{array}$ & $\begin{array}{l}10000 \text { people } \\
\text { maximum }\end{array}$ \\
\hline & $\begin{array}{l}\text { Clear border line of the city } \\
\text { building development }\end{array}$ & is absent & is desirable & is mandatory \\
\hline & Time of formation & one century & several centuries & a decade \\
\hline & Cost of land & $\begin{array}{l}\text { at the beginning } \\
\text { of development - } \\
\text { minimum }\end{array}$ & $\begin{array}{l}\text { at all stages of } \\
\text { development - } \\
\text { considerable }\end{array}$ & minimum \\
\hline & $\begin{array}{l}\text { Non-city (state) financing of } \\
\text { building development }\end{array}$ & considerable & in exceptional cases & complete \\
\hline & $\begin{array}{l}\text { Availability of low-density } \\
\text { building development of } \\
\text { mansion type }\end{array}$ & is available & is absent & $\begin{array}{l}\text { at the beginning } \\
\text { of development - } \\
\text { minimum }\end{array}$ \\
\hline & Building regulation & centralized, overall & moderate & \begin{tabular}{|l} 
centralized, \\
overall
\end{tabular} \\
\hline & Partition wall principle & is complied with & is complied with & is complied with \\
\hline & $\begin{array}{l}\text { Building development along } \\
\text { the streets in a "house-to- } \\
\text { house frontispieces" }\end{array}$ & is complied with & is complied with & is complied with \\
\hline & $\begin{array}{l}\text { Administrative constraints } \\
\text { related to building height } \\
\text { (number of storeys) }\end{array}$ & is carried out & is possible & is carried out \\
\hline & $\begin{array}{l}\text { Involvement of qualified } \\
\text { professionals into design and } \\
\text { construction activities }\end{array}$ & on an ongoing basis & possibly local & $\begin{array}{l}\text { on an ongoing } \\
\text { basis }\end{array}$ \\
\hline \multirow{3}{*}{$\begin{array}{l}\text { Quantity of civil } \\
\text { buildings within } \\
\text { the city building } \\
\text { development }\end{array}$} & $\begin{array}{l}\text { Number of administrative } \\
\text { buildings }\end{array}$ & significant & insignificant & insignificant \\
\hline & $\begin{array}{l}\text { Number of sovereign's and } \\
\text { noblemen palaces }\end{array}$ & significant & insignificant & insignificant \\
\hline & $\begin{array}{l}\text { Number of barracks and } \\
\text { military objects }\end{array}$ & large & insignificant & significant \\
\hline \multirow[t]{4}{*}{$\begin{array}{l}\text { Residential ribbon } \\
\text { buildings }\end{array}$} & $\begin{array}{l}\text { Length of a ribbon area along } \\
\text { the main frontispiece }\end{array}$ & $18.4-21.6 \mathrm{~m}$ & $3-9 \mathrm{~m}$ & \\
\hline & Number of storeys & up to 5 & up to $3-7$ & up to $3-4$ \\
\hline & $\begin{array}{l}\text { Number of residential units } \\
\text { within a building }\end{array}$ & $\begin{array}{l}\text { At the first stage }-1 \text {; } \\
\text { by } 1830-\text { dozens }\end{array}$ & $1-4$ & \\
\hline & $\begin{array}{l}\text { Frontispiece presentability } \\
\text { requirements }\end{array}$ & severe & moderate & moderate \\
\hline
\end{tabular}


- availability of a number of highly qualified professional craftsmen and architects in Petersburg;

- particular features of construction technology (brick-work walls, plastered frontispieces) allowed to restore buildings and change their frontispieces style at relatively low costs.

\section{Summary}

The analysis of historical approaches to development of residential buildings' construction in Saint Petersburg discovered solutions for some of up-to-date housing problems. It confirms the importance of concept design stage for building image, rather than architectural ideas:

- credit financing terms for small and large buildings;

- allocation of areas for building development.

The key to architectural issues can be found in administrative and financing field, transferring from macroeconomics to microeconomics level and switching from large residential communities to small projects, allocating relevant credit financing and small land areas.

\section{References}

Benois A.N. (1902) Zhivopisny Petersburg [Picturesque Petersburg] Mir iskusstva, vol. 7, No. 1, pp. 1-5 (In Russian) Gogol N.V. (1950) Ob arkhitekture nyneshnego vremeni [On contemporary architecture] Collected works in six volumes. Vol. 6 State publishing office of literature, Moscow, USSR, pp. 39-59 (In Russian)

Kirikov B.M., Kirikova L.A., Petrova O.V. (2004) Nevskiy prospekt. Architecturny putevoditel [Nevsky Prospect. A guide to architecture] ZAO Tsentrpoligraph, Moscow, Russia (In Russian)

Kirichenko E.I. (1963) O nekotorykh osobennostyakh evolyutsii gorodskikh mnogokvartirnykh domov vtoroy poloviny XIX veka - nachala XX veka [On some specific features of city blocks of flat' evolution, the second half of 19th-early 20th century]. Architecturnoye naslediye [Architectural heritage]: Issue 15. Stroyizdat, Moscow, USSR, pp. 153-170 (In Russian)

Kotelnikova I.G. (1974) Panorama Nevskogo prospekta V.S. Sadovnikova [Vista of Neva Prospect by V.S. Sadovnikov], Avrora, Leningrad, USSR. (In Russian)

Lisovsky V.G. (2004) Architectura Peterburga. Tri veka istorii [Petersburg architecture. Three centuries of history]. A.O. Slavia, Saint Petersburg, Russia. (In Russian)

Margolis A., Sementsov S. (2004) Sankt-Peterburg. Plany i karty [Saint Petersburg. Plans and maps]. ZAO Karta, Saint Petersburg, Russia (In Russian)

Ostrovsky V. (1979) Sovremennoye gradostroitelstvo [Contemporary urban planning]. Stroyizdat, Moscow, USSR. (In Russian)

Punin A.L. (1981) Architecturnye pamyatniki Peterburga. Vtoraya polovina XIX veka [Petersburg landmarks. The second half of the 19th century]. Lenizdat, Leningrad, USSR. (In Russian)

Savarenskaya T.F., Shvidkovsky D.O., Petrov F.A. (1989) Istoria gradostroitelnogo iskusstva [History of urban planning art]. Stroyizdat, Moscow. (In Russian)

Sementsov S.V. (2006(1)) Etapy formirovaniya prostranstvennoy sredy Sankt-Peterburga. Ch. 1. Istoricheskoe razvitie kvartalov i ikh reglamentatsiya [Stages of Saint Petersburg space arrangement. Part 1. Historical development of residential blocks and their regulation]. Vestnik grazhdanskikh ingenerov [Bulletin of Civil Engineers], 2 (7): pp. 15-20. (In Russian)

Sementsov S.V. (2006(2)) Etapy formirovaniya prostranstvennoy sredy Sankt-Peterburga. Ch. 2. Istoricheskoe razvitie uchastkov (sistemy razbivki i zastroyki uchastkov) i ikh reglamentatsiya [Stages of Saint Petersburg space arrangement. Part 2. Historical development of areas (planning and building development systems) and their regulation]. Vestnik grazhdanskikh ingenerov [Bulletin of Civil Engineers], 3(8): pp. 21-26. (In Russian)

Hallmann, Gerhard. (1978) Leningrad (Kunstgeschichtliche Städtebücher), 3. Auflage. VEB E.A. Seemann-Verlag, Leipzig, DDR

Maass, Michael. Hrsg (1990) Planstaedte der Neuzeit: vom 16. bis zum 18. Jahrhundert. Eine Ausstellung des Landes Baden-Wuerttemberg, veranstaltet vom Badischen Landesmuseum Karlsruhe. Verlag Braun. Karlsruhe. Deutschland. (In Russian)

Shvidkovsky, D. (2007) Russian architecture and the West. Yale University Press. New Haven. United States. 